\title{
EFFECT OF POST-POLYMERIZATION HEAT TREATMENTS ON THE CYTOTOXICITY OF TWO DENTURE BASE ACRYLIC RESINS
}

\author{
EFEITO DE TRATAMENTOS TÉRMICOS APÓS A POLIMERIZAÇÃO SOBRE A \\ CITOTOXICIDADE DE DUAS RESINAS ACRÍLICAS PARA BASE DE PRÓTESES
}

\author{
Janaina Habib JORGE ${ }^{1}$, Eunice Teresinha GIAMPAOLO², Carlos Eduardo VERGANI ${ }^{3}$, Ana Lúcia MACHADO², \\ Ana Cláudia PAVARINA ${ }^{3}$, Iracilda Zeppone CARLOS ${ }^{4}$
}

\author{
1- DDS, MSc, PhD Student, Department of Dental Materials and Prosthodontics, São Paulo State University, Araraquara Dental School, São \\ Paulo, Brazil. \\ 2- DDS, MSc, PhD Associate Professor, Department of Dental Materials and Prosthodontics, São Paulo State University, Araraquara Dental \\ School, São Paulo, Brazil. \\ 3- DDS, MSc, PhD Assistant Professor, Department of Dental Materials and Prosthodontics, São Paulo State University, Araraquara Dental \\ School, São Paulo, Brazil. \\ 4- DDS, MSc, PhD Associate Professor, Department of Clinical Analysis, São Paulo State University, Araraquara Pharmaceutical School, São
} Paulo, Brazil.

Corresponding address: Dra. Janaina Habib Jorge - Department of Dental Materials and Prosthodontics - Araraquara Dental School R. Humaitá, n 1680, Araraquara, SP, Brazil - Cep.: 14801-903 - phone: 55-16-3301 6410 - fax: 55-16-3301 6406 - e-mail: janainahj@bol.com.br

Received: November 16, 2005 - Modification: March 29, 2006 - Accepted: June 6, 2006

\begin{abstract}
$I$ ntroduction: Most denture base acrylic resins have polymethylmethacrylate in their composition. Several authors have discussed the polymerization process involved in converting monomer into polymer because adequate polymerization is a crucial factor in optimizing the physical properties and biocompatibility of denture base acrylic resins. To ensure the safety of these materials, in vitro cytotoxicity assays have been developed as preliminary screening tests to evaluate material biocompatibility. ${ }^{3} \mathrm{H}$-thymidine incorporation test, which measures the number of cells synthesizing DNA, is one of the biological assays suggested for cytotoxicity testing. Aim: The purpose of this study was to investigate, using ${ }^{3} \mathrm{H}$-thymidine incorporation test, the effect of microwave and water-bath post-polymerization heat treatments on the cytotoxicity of two denture base acrylic resins. Materials and Methods: Nine disc-shaped specimens (10 x $1 \mathrm{~mm}$ ) of each denture base resin (Lucitone 550 and QC 20) were prepared according to the manufacturers' recommendations and stored in distilled water at $37^{\circ} \mathrm{C}$ for $48 \mathrm{~h}$. The specimens were assigned to 3 groups: 1) post-polymerization in a microwave oven for $3 \mathrm{~min}$ at $500 \mathrm{~W}$; 2) post-polymerization in water-bath at $55^{\circ} \mathrm{C}$ for $60 \mathrm{~min}$; and 3) without post-polymerization. For preparation of eluates, 3 discs were placed into a sterile glass vial with $9 \mathrm{~mL}$ of Eagle's medium and incubated at $37^{\circ} \mathrm{C}$ for $24 \mathrm{~h}$. The cytotoxic effect of the eluates was evaluated by ${ }^{3} \mathrm{H}$-thymidine incorporation. Results: The results showed that the components leached from the resins were cytotoxic to L929 cells, except for the specimens heat treated in water bath ( $<<0.05)$. Compared to the group with no heat treatment, water-bath decreased the cytotoxicity of the denture base acrylic resins. Conclusion: The in vitro cytotoxicity of the tested denture base materials was not influenced by microwave post-polymerization heat treatment.

Uniterms: Cytotoxicity; Cell culture; Denture base resins.
\end{abstract}

\section{RESUMO}

I

ntrodução: A maioria das resinas acrílicas utilizadas para confecção de bases de próteses é composta pelo polimetacilato de metila. Muitos autores têm discutido o processo de polimerização dessas resinas em relação à conversão do monômero em polímero devido a sua importância na melhora da biocompatibilidade e das propriedades físicas. Para assegurar a utilização desses materiais, testes preliminares de citotoxicidade in vitro têm sido desenvolvidos para avaliação da biocompatibilidade. Um dos ensaios biológicos sugeridos para a análise da citotoxicidade é o teste de incorporação de ${ }^{3} \mathrm{H}$-timidina, o qual mede o número de células por meio da síntese de DNA. Objetivo: O objetivo do presente estudo foi avaliar, por meio do teste de incorporação de ${ }^{3} \mathrm{H}$-timidina, a citotoxicidade de duas resinas acrílicas para base de próteses submetidas aos tratamentos em microondas e em banho de água após a polimerização. Material e Método: Nove corpos-de-prova em forma de discos $(10 \mathrm{x} 1 \mathrm{~mm})$ foram confeccionados com as resinas acrílicas Lucitone 550 e QC 20 de acordo com as instruções dos fabricantes, e foram armazenados em água destilada a $37^{\circ} \mathrm{C}$ por $48 \mathrm{~h}$. Os corpos-deprova foram divididos em três grupos: 1) tratamento em forno de microondas por $3 \mathrm{~min}$ a $500 \mathrm{~W}$; 2) tratamento em banho de água a $55^{\circ} \mathrm{C}$ por $60 \mathrm{~min}$; e 3) sem tratamento térmico. Extratos foram preparados pela colocação de 3 discos em tubos de ensaio estéreis com 9 mL de meio de cultura Eagle e incubação a $37^{\circ} \mathrm{C}$ por $24 \mathrm{~h}$. O efeito citotóxico dos extratos foi avaliado utilizando o teste de incorporação de ${ }^{3} \mathrm{H}$-timidina. Resultados: Os resultados indicaram que os componentes liberados pelas resinas foram citotóxicos para as células L929 exceto para as amostras tratadas em banho de água ( $<$ 0.05). Em comparação com o grupo sem tratamento, o banho de água diminuiu a citotoxicidade das resinas acrílicas. Conclusão: $\mathrm{O}$ tratamento em microondas não influenciou a citotoxicidade das resinas acrílicas para bases de próteses.

Unitermos: Citotoxicidade; Cultura de células; Resina acrílica. 


\section{INTRODUCTION}

Acrylic resin or polymethylmethacrylate has been used as a denture base material for over 60 years ${ }^{13}$. According to polymerization mode, acrylic resins may be classified as heatpolymerized, auto-polymerized, microwave-polymerized and visible light-cured. Heat-polymerized denture base resins may leach out residual monomers and other chemically reactive, toxic components that might cause adverse reactions in the oral mucosa adjacent to the dentures ${ }^{11}$. These responses have been attributed to residual methyl methacrylate monomer that may leach from denture base resins into saliva ${ }^{26}$. In addition, leaching of formaldehyde, methyl methacrylic acid and benzoic acid from dental acrylic resin materials has been detected ${ }^{19,25,30}$. Several methods for reducing the residual monomer contents and, consequently, the cytotoxicity of denture base resins have been described ${ }^{10}$. Blagojevic and Murphy ${ }^{2}$ reported that the residual monomer content of an autopolymerizing acrylic resin was reduced by nearly a quarter after microwaving. In addition, to minimize the amount of residual monomer released from denture following completion of polymerization, several authors have suggested that the prostheses should be stored in water prior to placement ${ }^{19,27}$. Tsuchiya, et al. ${ }^{30}$ observed that the preleaching in water for $60 \mathrm{~min}$ at $50^{\circ} \mathrm{C}$ reduced the subsequent release of methyl methacrylate and formaldehyde, which decreased their cytotoxic potential. However, different results were observed in a previous study in which the cytotoxicity of three denture base resins polymerized according to the manufacturers' instructions was not decreased by either water-bath or microwave postpolymerization treatments ${ }^{11}$. Depending on the polymerization temperature and time, variable amounts of residual monomer are left in the polymer ${ }^{6}$, leading to different degrees of cytotoxicity $^{13}$. Thus, it is reasonable to imply that a correct choice of curing cycle and post-polymerization treatment could produce favorable results.

Testing of dental materials by using cell culture has been proven suitable as an alternative to controversial animal experiments and relatively simple to perform, reproducible and cost-effective ${ }^{19}$. Different parameters are used to monitor the cytotoxic effects of dental materials, such as inhibition of cell growth, cytolysis, membrane or cytoplasmic markers and changes in metabolic activity ${ }^{1} \cdot{ }^{3} \mathrm{H}$-thymidine incorporation test, which measures the number of cells actively synthesizing DNA, is one of the biological assays suggested for cytotoxicity testing ${ }^{7,28}$. Although this technique has some disadvantages, including the need of expensive special equipment and production of radioactive waste, studies have shown that ${ }^{3} \mathrm{H}$-thymidine incorporation assay is more sensitive to resin toxicity than other tests ${ }^{11,29}$.

The purposes of this study were to evaluate the effect of water-bath and microwave post-polymerization heat treatments on the cytotoxicity of two denture base acrylic resins and to compare the cytotoxicity these materials by ${ }^{3} \mathrm{H}$ thymidine incorporation assay. The hypothesis that postpolymerization heat treatments could decrease the cytotoxicity of acrylic denture base resins was tested.

\section{MATERIALS AND METHODS}

\section{Specimen preparation}

The denture base acrylic resins used in this study were Lucitone 550 - lot 65173 (Dentsply International Inc., Chicago, IL, USA) and QC 20 - lot 65210 (Dentsply International Inc., Chicago, IL, USA). Under aseptic conditions, 9 disc-shaped specimens of each resin (1 mm thick; $10 \mathrm{~mm}$ in diameter) were fabricated and polymerized according to the manufacturers' specifications. The following polymerization cycles were employed: Lucitone 550 was processed for $9 \mathrm{~h}$ at $71^{\circ} \mathrm{C}$ and QC 20 was processed by placing the flask in boiling water, removing heat for 20 min, returning to boil and boiling for $20 \mathrm{~min}$. Excess flash was removed with a sterile trimming bur. The specimens were stored in distilled water at $37^{\circ} \mathrm{C}$ for $48 \mathrm{~h}^{11}$. To assess the biologic effect of the post-polymerization heat treatments, the discs were assigned to 3 groups: 1 ) postpolymerization in a microwave oven for $3 \mathrm{~min}$ at $500 \mathrm{~W}$ in dry conditions ${ }^{9} ; 2$ ) post-polymerization in water bath at $55^{\circ} \mathrm{C}$ for $60 \mathrm{~min}$; and 3) no post-polymerization heat treatment. Before cytotoxicity testing, the discs were ultrasonically cleaned in distilled water for $20 \mathrm{~min}$ and exposed to ultraviolet light for another 20 min to kill microorganisms that might have contaminated the discs during fabrication ${ }^{11,27}$.

\section{Eluate preparation}

Eluates of the materials were prepared by placing 3 discs into a sterile glass vial (Costar, Corning Incorporated, Corning, NY, USA) with $9 \mathrm{~mL}$ of Eagle's medium supplemented with antibiotic ( $80 \mu \mathrm{g} / \mathrm{mL}$ of gentamycin) and fetal bovine serum and then incubating at $37^{\circ} \mathrm{C}$ for $24 \mathrm{~h}$. A medium without discs was also incubated and diluted as described above to serve as negative control.

\section{Cell culture}

Mouse fibroblast cells (L929) were propagated in Eagle's minimum essential medium (Institute Adolfo Lutz, São Paulo, SP, Brazil) supplemented with $80 \mu \mathrm{g} / \mathrm{mL}$ of gentamycin and $7.5 \% \mathrm{v} / \mathrm{v}$ fetal bovine serum. The culture was maintained at $37^{\circ} \mathrm{C}$ in an atmosphere of $5 \% \mathrm{CO}_{2} / 95 \%$ air.

\section{${ }^{3} \mathrm{H}$-thymidine incorporation assay}

DNA synthesis in fibroblasts was assessed by measuring the incorporation of ${ }^{3} \mathrm{H}$-thymidine (Amershan Pharmacia Biotech do Brazil Ltda., São Paulo, SP, Brazil). L929 mouse fibroblasts $\left(1 \times 10^{4}\right.$ cell $\left./ \mathrm{mL}\right)$ in $100 \mu \mathrm{L}$ of the Eagle's medium were seeded into 96-well culture plates and incubated at $37^{\circ} \mathrm{C}$ for $24 \mathrm{~h}$ in an air atmosphere containing $5 \% \mathrm{CO}_{2}$. After $24 \mathrm{~h}$ of incubation, the culture medium was replaced by $20 \mu \mathrm{L}$ medium containing $0.25 \mu \mathrm{Ci}$ of ${ }^{3} \mathrm{H}-$ thymidine. Additional $50 \mu \mathrm{L}$ eluate and $50 \mu \mathrm{L}$ fresh medium were added to each well of a 96-well culture plate and incubated for another $24 \mathrm{~h}$ at $37^{\circ} \mathrm{C}$ in an air atmosphere containing $5 \% \mathrm{CO}_{2}$. Isotope incorporation into DNA was measured after $24 \mathrm{~h}$ incubation. After $24 \mathrm{~h}$ of exposure to ${ }^{3} \mathrm{H}-$ thymidine, the cells were harvested onto fiber filters using a multichannel automated harvester (Unifilter 96 GF/C, Packard 
Instrument Company, Meriden, CT, USA) and the incorporated radioactivity was measured using a scintillation counter (Unifilter 96 GF/C, Packard Instrument Company, Meriden, CT, USA). Four wells were used for each experimental group. All experiments were performed twice, and each consisted of quadruplicate. This protocol was based on the outcomes of previous studies ${ }^{3,11,18}$ in which the desired reproducibility was assured.

Data were analyzed on a log scale because log transformed data fitted a normal distribution. These data were analyzed by two-way analysis of variance to determine differences in cytotoxicity on the basis of independent variables of material and post-polymerization heat treatments. Tukey's test was used to determine significant differences between group means at 5\% significance level.

\section{RESULTS}

DNA synthesis, based on mean cpm (counts per minute) of the incorporated radioisotope is shown on Table 1. Twoway ANOVA revealed that the specimens heat treated in water bath produced significantly lower inhibition of DNA synthesis $(\mathrm{p}<0.05)$ than those without post-polymerization heat treatments, which resulted in a larger number of viable cells. The cytotoxicity of the materials was not affected by post-polymerization microwaving $(\mathrm{p}>0.05)$. Comparing the cytotoxic potential of the tested denture base resins, there were no significant differences ( $\mathrm{p}>0.05$ ) in the mean isotope incorporation into cellular DNA, regardless the group evaluated.

\section{DISCUSSION}

This study investigated the effects of postpolymerization heat treatments on the cytotoxicity of two denture base acrylic resins. Biocompatibility of dental materials has been evaluated by in vitro and in vivo studies and human clinical trials ${ }^{27}$. Testing of dental materials by cell culture methods are relatively simple to perform, reproducible and cost effective, in addition to being accurately controlled. Different parameters, such as inhibition of cell growth, cytolysis, effects on membrane or cytoplasmic markers and changes in metabolic activity, have been used to monitor cytotoxic effects of dental materials ${ }^{8}$. Measurement of DNA synthesis by ${ }^{3} \mathrm{H}$-thymidine incorporation ${ }^{29}$ and analysis of the metabolism of yellow methyltetrazolium salt (MTT) by mitochondrial dehydrogenase of active cells into blue formazan crystals are commonly used biologic assays for cytotoxicity testing ${ }^{29}$.

In this study, ${ }^{3} \mathrm{H}$-thymidine incorporation assay was used to determine the cytotoxicity of two acrylic denture base resins on L929 murine cell line because it has proven more sensitive than other methods ${ }^{3,11,29}$. The results showed that QC 20 and Lucitone 550 resin specimens not submitted to post-polymerization heat treatments were cytotoxic when compared to the negative control.

The effects of toxic substances leached from acrylic resins on tissues have been reported by clinical studies ${ }^{22}$,

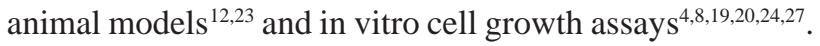
Denture base resins exhibit various degrees of in vitro cytotoxicity and in vivo allergic responses, probably caused by unreacted components remaining after the polymerization process. Residual monomer content varies with the methods and the conditions of polymerization ${ }^{13,31}$. Studies have demonstrated that although the cytotoxic effect of residual monomer may last for several days after polymerization, it can be minimized if the dentures are stored in water for 24 $\mathrm{h}^{15,19}$. Therefore, some authors have suggested that soaking polymerized dentures in water may be beneficial in reducing intraoral monomer release ${ }^{19,30}$. Depending on the polymerization temperature and time, different amounts of residual monomer remain unreacted thus resulting in different degrees of cytotoxicity ${ }^{6,13}$. In a previous study ${ }^{11}$, Lucitone 550 specimens polymerized following the short cycle recommended by the manufacturer $\left(90 \mathrm{~min}\right.$ at $73^{\circ} \mathrm{C}$ and then $100^{\circ} \mathrm{C}$ boiling water for $30 \mathrm{~min}$ ) were proven to be cytotoxic. It has been demonstrated that the polymerization cycle of heat-polymerized acrylic resins should include a final boiling treatment for at least $1 \mathrm{~h}$ in order to achieve maximum monomer conversion ${ }^{6}$. The long polymerization cycle recommended for Lucitone 550 (for $9 \mathrm{~h}$ at $71^{\circ} \mathrm{C}$ ) did not include a terminal boil, which probably contributed to the

TABLE 1- ${ }^{3} \mathrm{H}$-thymidine incorporation assay results for all experimental and control groups (log counts per minute)

\begin{tabular}{|c|c|c|c|c|c|c|c|}
\hline & \multicolumn{2}{|c|}{ Microwave } & \multicolumn{2}{|c|}{ Water bath } & \multicolumn{2}{|c|}{ No post polymerization } & \multirow[t]{2}{*}{ Control Group } \\
\hline & Lucitone & QC-20 & Lucitone & QC-20 & Lucitone & QC-20 & \\
\hline & 2.95 & 3.36 & 3.56 & 3.38 & 3.26 & 3.31 & 3.38 \\
\hline & 3.13 & 3.32 & 3.42 & 3.43 & 3.21 & 3.36 & 3.34 \\
\hline & 3.15 & 3.18 & 3.34 & 3.45 & 3.11 & 3.24 & 3.55 \\
\hline & 3.34 & 3.35 & 3.38 & 3.35 & 3.12 & 3.11 & 3.38 \\
\hline Mean & $3.14^{a, b}$ & $3.30 \mathrm{a}, \mathrm{b}$ & $3.42^{a}$ & $3.40^{a}$ & $3.17^{b}$ & $3.26^{b}$ & 3.41 a,b \\
\hline SD & 0.16 & 0.08 & 0.09 & 0.04 & 0.07 & 0.11 & 0.09 \\
\hline
\end{tabular}

Means designated with the same superscript were not statistically different $(P>0.05)$. 
higher residual monomer levels observed for this resin. Consequently, Lucitone 550 specimens were also cytotoxic in this study. Similar results were observed for QC 20 specimens. According to Harrison and Huggett ${ }^{6}$, the reverse polymerization cycle of QC 20 acrylic resin produced high levels of residual monomer (1.21\%), which might be responsible for the cytotoxicity observed in this study.

Post-polymerization water bath was effective in reducing the cytotoxicity of both Lucitone 550 and QC 20 denture base resins. This might be explained by different mechanisms. It has been observed that residual monomer content after polymerization can be decreased by diffusion in water ${ }^{31}$. In addition, as the release of residual monomer is a temperature-dependent process, diffusion is enhanced with the increase of temperature ${ }^{15,31}$. It has also been shown that the decrease in residual monomer levels after resin polymerization is due to further polymerization at the sites of active radicals, and that monomer molecules should diffuse more rapidly to these active sites at higher temperatures, which should increase monomer level fall rate ${ }^{15,16}$. Therefore, the possible lower levels of residual monomer produced by the mechanisms of diffusion and post-polymerization reaction may help explaining the lower cytotoxicity of the denture base resins submitted to waterbath post-polymerization treatment.

Post-polymerization microwaving was based on previous studies $^{5,32}$, which reported that the residual monomer levels decreased with microwave irradiation. Microwaves act only on the monomer content, which decreases in the same proportion as the polymerization degree increases ${ }^{5}$. Unexpectedly, microwave post-polymerization treatment did not decrease the cytotoxicity of the resins tested in this study. This was surprising because our hypothesis was that microwaving could decrease the content of leachable residual monomer of the acrylic denture base resins and their cytotoxicity. In this study, the materials were microwaved in dry conditions and, hence, reduction in residual monomer levels due to water diffusion was not expected. It seems that the increase of the polymerization degree produced by microwaving was not sufficient to decrease the cytotoxic potential of the denture base resins. This may be attributed to a variety of potentially toxic substances eluted from denture base resins, which were unlikely to be influenced by microwave post-polymerization. These substances include formaldehyde, methacrylic acid, plasticizers, organic additives, benzoic acid, and biphenyl and phenyl benzoate ${ }^{14,21}$. It may also be speculated that oxygen might have competed for free radicals with the residual monomer on specimen surface thus inhibiting any further polymerization ${ }^{17}$. In view of this, studies investigating microwave post-polymerization heat treatments should add to their methodology the immersion of the specimens in water during microwaving. In the present study, the release of components from the acrylic resins was not measured, but this would help explaining the biological risks of this type of material.

Even though the results of initial cytotoxicity tests cannot be immediately extrapolated to clinical conditions, they are important to define the biologic behavior of dental materials and their constituents. It may be suggested that denture bases fabricated from Lucitone 550 and QC 20 acrylic resins should be soaked in water for $48 \mathrm{~h}$ and further polymerized in hot water $\left(55^{\circ} \mathrm{C}\right)$ for $1 \mathrm{~h}$ to reduce their cytotoxicity. This treatment may potentially reduce the incidence of hypersensitivity reaction among denture wearers.

\section{CONCLUSIONS}

1. Water bath post-polymerization heat treatment at $55^{\circ} \mathrm{C}$ for 60 min improved the biocompatibility of the materials tested.

2. Microwave post-polymerization heat treatment had no effect on the cytotoxicity of the materials tested.

\section{ACKNOWLEDGEMENTS}

This investigation was supported by The State of São Paulo Research Foundation (FAPESP; grant No. 01/14004$0)$.

\section{REFERENCES}

1- Barron DJ, Schuster GS, Caughman GB, Lefebvre CA. Biocompatibility of visible light-polymerized denture base resins. Int J Prosthodont. 1993;6:495-501.

2- Blagojevic V, Murphy VM. Microwave polymerization of denture base materials. A comparative study. J Oral Rehabil. 1999;26:804-8.

3- Campanha NH. et al. Cytotoxicity of hard chairside reline resins: effect of microwave irradiation and water bath postpolymerization treatments. Int J Prosthodont. 2006;2:151-7.

4- Cimpan MR, Cressey LI, Skaug N, Halstensen A, Lie SA, Gjertsen BT, Matre R. Patterns of cell death induced by eluates from denture base acrylic resins in U-937 human monoblastoid cells. Eur J Oral Sci. 2000;108:59-69.

5- De Clerk JP. Microwave polymerization of acrylic resins used in dental prostheses. J Prosthet Dent. 1987;57:650-9.

6- Harrison A, Huggett R. Effect of the curing cycle on residual monomer levels of acrylic resin denture base polymers. J Dent. 1992;20:370-4.

7- Hensten-Pettersen A, Wictorin L. The cytotoxic effect of denture base polymers. Acta Odontol Scand. 1981;39:101-6.

8- Hensten-Pettersen A. Comparison of the methods available for assessing cytotoxicity. Int Endod J. 1988;21:89-99.

9- Ilbay SG, Güvener S, Alkumru HN. Processing dentures using a microwave technique. J Oral Rehabil. 1994;21:103-9.

10- Jorge JH, Giampaolo ET, Vergani CE, Machado AL, Pavarina AC, Carlos IZ. Cytotoxicity of denture base resins: Effect of water bath and microwave postpolymerization heat treatments. Int J Prosthodont 2004;17:340-4. 
11- Jorge JH, Giampaolo ET, Vergani CE, Machado AL. Cytotoxicity of denture base resins: a literature review. J Prosthet Dent. 2003;90:190-3.

12- Kallus T. Evaluation of the toxicity of denture base polymers after subcutaneous implantation in guinea pigs. J Prosthet Dent. 1984;52:126-34.

13- Kedjarune U, Charoenworaluk N, Koontongkaluk S. Release of methyl methacrylate from heat-polymerized and autopolymerized resins: Cytotoxicity testing related to monomer. Aust Dent J. $1999 ; 44: 25-30$

14- Koda T, Tsuchiya H, Yamauchi M, Ohtani S, Takagi N, Kawano J. Leachability of denture-base acrylic resins in artificial saliva. Dent Mater. 1990;6:13-6.

15- Lamb DJ, Ellis B, Priestley D. Loss into water of residual monomer from autopolymerizing dental acrylic resin. Biomaterials. 1982;3:1559 .

16- Lamb DJ, Ellis B, Priestley D. The effects of process variables on levels of residual monomer in autopolymerizing dental acrylic resin. J Dent. 1983;11:80-8.

17- Lee SY, Lai YL, Hsu TS. Influence of polymerization conditions on monomer elution and microhardness of autopolymerized polymethyl methaclylate resin. Eur J Oral Sci. 2002;110:179-83.

18- Lefebvre CA, Schuster GS, Marr JC, Knoernschild KL. The effect of $\mathrm{pH}$ on the cytotoxicity of eluates from denture base resins. Int $\mathrm{J}$ Prosthodont. 1995;8:122-8.

19- Lefebvre CA, Schuster GS, Caughman GB, Caughman WF. Effects of denture base resins on oral epithelial cells. Int J Prosthodont. 1991;4:371-6.

20- Lefebvre CA, Schuster GS. Biocompatibility of visible lightcured resin systems in prosthodontics. J Prosthet Dent. 1994; 71:17885.

21- Lygre H, Solheim E, Gjerdet NR. Leaching from denture base materials in vitro. Acta Odontol Scand. 1995: 53;75-80.

22- Mac Cabe JF, Basker RM. Tissue sensitivity to acrylic resin. A method of measuring the residual monomer content and its clinical application. Br Dent J. 1976;18: 347-50.

23- Nagem FH, Chiodi NJ, Araujo PA. Biocompatibility of acrylic resins implants in connective tissue. Estomat \& Cult. 1973;7:120-3.

24- Nakamura M, Kawahara H. Long-term biocompatibility test of denture base resins in vitro. J Prosthet Dent. 1984;52:694-9.

25- Okita N, Hensten-Pettersen A. In vitro cytotoxicity of tissue conditioners. J Prosthet Dent. 1991;66: 656-9.

26- Ruyter IE. Release of formaldehyde from denture base polymers. Acta Odontol Scand. 1980;38:17-27.

27- Schuster GS, Lefebvre CA, Dirksen TR, Knoernschild KL, Caughman GB. Relationships between denture base resin cytotoxicity and cell lipid metabolism. Int J Prosthodont. 1995;8:580-6.

28- Sheridan PJ, Koka S, Ewoldsen NO, Lefebvre CA, Lavin MT. Cytotocity of denture base resins. Int J Prosthodont. 1997;10:73-7.

29- Tang ATH, Li J, Ekstrand J, Liu Y. Cytotoxicity tests of in situ polymerized resins: methodological comparisons and introduction of a tissue culture insert as a testing device. J Biomed Mater Res. 1999:45;214-22.
30- Tsuchiya H, Hoshino Y, Tajima K, Takagi N. Leaching and cytotoxicity of formaldehyde and methyl methacrylate from acrylic resin denture base materials. J Prosthet Dent. 1994;71:618-24.

31- Vallittu PK, Ruyter IE, Buykuilmaz S. Effect of polymerization temperature and time on the residual monomer content of denture base polymers. Eur J Oral Sci. 1998;106:588-93.

32- Yunus N, Harrison A, Huggett R. Effect of microwave irradiation on the flexural strength and residual monomer levels of an acrylic resin repair material. J Oral Rehabil. 1994;21:641-8. 